\title{
DETERMINING THE TOURIST ATTRACTIVE REGIONS BY GIS ANALYSIS USING HEATMAPS
}

\author{
Viktoriya KULYK ${ }^{1^{*}}$, Rostyslav SOSSA ${ }^{2}$ \\ ${ }^{1}$ Geoinformation Systems for Territory Management Department, \\ Kyiv National University of Construction and Architecture \\ ${ }^{2}$ Department of Cartography and Geospatial Modelling, \\ Lviv Polytechnic National University
}

Received 31 January 2018; accepted 14 March 2018

\begin{abstract}
In this article, we explore heatmaps as a method of applying GIS-technologies to study the distribution of tourist and recreational objects. We analyze the foundations of heatmaps, their features and advantages among the cartographic methods of research, and examples of their application in the tourism industry. Using a database in QGIS, we create heatmaps of tourist objects in Ukraine that help to determine and visualize the tourist attractive regions of the country.
\end{abstract}

Keywords: heatmap, tourist object, tourist and recreational object, tourist attractive region, tourist attractiveness, cartography, QGIS.

\section{Introduction}

Tourism consolidates people from different countries, enabling them to get familiar with the world cultural heritage, it teaches to be peaceful and tolerant. It is also an important source of economic development and an effective stimulus for positive changes in the society. Tourism industry is one of the most promising, dynamic and profitable sectors of the world economy that effectively utilizes natural, cultural and historical capacities. Professional use of these capacities creates opportunities for obtaining substantial revenues. The long-term economic benefits within the tourism industry can be obtained if tourism is actively developed and wisely managed. This process requires analyzing the development of the tourism industry and studying the territorial distribution of tourism. The cartographic research methods based on modern information technologies, including GIS can greatly help for such analyses and studies.

Analysis of cartographic information using GIS allows to determine spatial regularities of distribution of processes or phenomena, as well as to analyze conditions and factors that affect their allocation and to forecast their territorial development (Mitchell, 2000). The GIS analysis facilitates the finding of trends and anomalies in the distribution of particular phenomena, and it can serve as a tool for identifying tourist attractive areas. The cartographic research methods using GIS, and in particular using heatmaps can be used for predictions of development of tourism activities.

\section{Analysis of recent publications}

In scientific publications significant attention is paid to the need of using modern information technologies in the development of tourism, and to the innovative technologies in the tourism industry (Glebova, 2012; Kal'naDubinyuk, 2011; Lutay, 2012; Mel'nik, 2009; Mel'nichenko, 2008; Khudo, 2000). The literature also puts a huge emphasis on the question of developing practical guidelines of promoting tourist products through internet in order to reveal information about specific types of consumer service, and on analyzing of information systems of tourist data processing (Shakhovs'ka, 2008).

One methodology of identifying priorities in the development of tourist and recreational territories using the GIS technology is based on zoning through assigning a tourist attractiveness score to each area (Danil'chuk, 2008). A promising methodology of determining attractive tourist regions and analyzing the distribution of tourist objects in the territory is based, in my opinion, on creation of heatmaps using GIS and on interpreting them.

${ }^{*}$ Corresponding author. E-mail: viktoriya.b.kulik@gmail.com 


\section{The objective of the article}

The objective of this article is to study methodological aspects of application of GIS technologies to analyze the territorial distribution of tourist objects using heatmaps. This article contributes to improvements of tourism management through the usage of the cartographic research methods for studying areas attractive to tourists.

\section{The methodology of applying GIS-technologies to study the distribution of tourist and recreational objects}

At the heart of most of the methodological approaches used to determine attractive tourist places is the comprehensive evaluation of their natural and socio-economic resources. It is traditionally thought that natural objects (landscapes, water objects, forests, mountains, and other unique objects of nature) and cultural and historical objects (monuments, architectural objects, sacred places, religious buildings, fortresses, castles and their ruins) are the most interesting for tourists. The availability of social infrastructure is also important for tourists, and such availability has a positive effect on tourism in a particular region. Here there is a direct relationship: the higher the level of socio-economic development of a region is (developed transport infrastructure, available accommodation, cultural and entertainment centers) the more attractive the region is for tourists (Danil'chuk, 2008; Kolotova, 1999).

A combination of different tourist and recreational resources in the same area indicates that the area is of a significant interest to tourists. This is the reason for tour operators to encourage tourists to visit these areas. The assessment of tourist attractiveness of a region should also include climatic and ecological factors. These factors may increase or decrease the attractiveness of the region. However, the correlation is not always positive. An example is the Chernobyl exclusion zone, which is of interest to some tourists despite its environmental hazard.

The cartographic research methods help to identify the level of tourist attractiveness. The visualization with maps of tourist and recreational objects (of various types or categories) that are shown in various tourist maps is helpful for detecting certain regularities of their location. It also helps to make decisions regarding the improvements of the situation. The geoinformatic approach is more fundamental than visualization for identifying attractive tourist regions. It involves creating and using a database of various tourist and recreational objects, and conducting an analysis and interpretation of the data.

The tourist attractiveness of regions can be determined using spatial analysis in GIS applications that is used to determine characteristics of tourist objects and their geoprocessing. Because the tourist objects are unevenly located on the territory, it makes sense to use spatial interpolation, the results of which are shown on the so-called statistical surface. This can be done by creating heatmaps. The maps allow to present information in easily understandable form. They are good for visualization purposes. In addition, they help to analyze the distribution of statistical data and in particular to show the areas of higher density of objects or phenomena and clusters of their activity. Heatmaps is an appropriate tool for visualization of points and polygonal objects and tourist objects are such objects.

Heatmaps is a particular type of graphical representation of data that consists of a set of cells, in which each cell is painted in a particular color according to a specific value attributed to the cell. The term "heat" in this context is seen as a high concentration of geographical objects in a particular place. Heatmaps are sometimes considered to be the same as hotspots maps, but they differ. Heatmaps show the distribution of objects or phenomena across the entire surface, while hotspot maps show numerical values only at concrete points (Eck, 2005).

More generally, heatmaps can be viewed as the surfaces of densities (it is for convenience that they are created in GIS applications as a raster layer, in which the value of each cell is computed). Such surface density well illustrates the location of concentration of points or linear objects (Mitchell, 2000).

Sometimes, the term "heatmap" is applied to cartograms, but this is inappropriate because cartograms are cartographic images that show the distribution of a particular phenomenon on a map across certain territorial units (for example, across administrative units). Cartograms show each territorial unit in one color, indicating one particular value attributed to that unit, therefore ignoring geographical zoning of the considered phenomenon (Salishchev, 1990). On the other hand, heatmaps show the distribution of a phenomenon across the entire territory, and this phenomenon is generally associated with the geographical zoning. In terms of traditional cartography, heatmaps look similar to a quantitative background or to isolines. In fact, we would categorize a heatmap to be fundamentally similar to pseudoisolines - a method of cartographic imaging used to show characteristics of objects of dispersed spreading (these are often socio-economic objects), and that creates a conditionally continuous surface. The surface created by the method is also called statistical surface because it is constructed based on statistics of the data (Bozhok, Molochko, \& Ostroukh, 2014).

One way to create a heatmap is by interpolation of discrete points that leads to the creation of a surface. For this process it is necessary to define the following three main criteria:

- the size of the cell in the raster layout (which determines the level of precision of the constructed surface);

- the search radius around each cell (which determines the coefficient of density);

- the type of calculations (which is used in the interpolation of surface density) (Gis lounge, 2017).

Heatmaps were first used to show financial market information in real time. Later on, heatmaps were used 
in molecular and structural biology, epidemiology, ecology, climatology, urban planning, and even policy (Babicki, et. al. 2016). Nowadays, there are several online services in internet to create heatmaps. For example, Heatmap Tools uses the power of Google Maps API to visualize different GIS data and to create heatmaps. In this service, there are various display options (radius of the markers, color, opacity and others) (Heatmaptool, 2017). Other services to create heatmaps include Openheatmap, eSpatial Mapping Software, Heatmapper (Openheatmap, 2017; eSpatial, 2017; Heatmapper, 2017).

One example of using heatmaps for the mapping of tourist activity is Sightsmap (Sightsmap, 2017). This program creates heatmaps of tourist popularity. It analyses

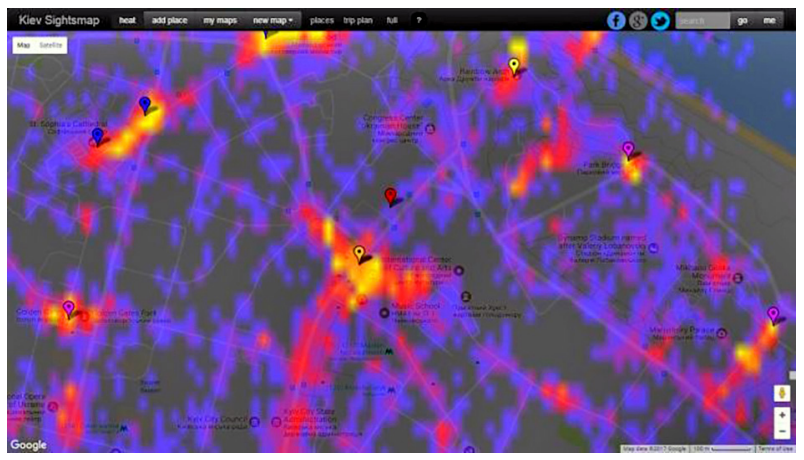

Figure 1. A fragment of a heatmap (the central part of Kyiv) (Sightsmap, 2017)

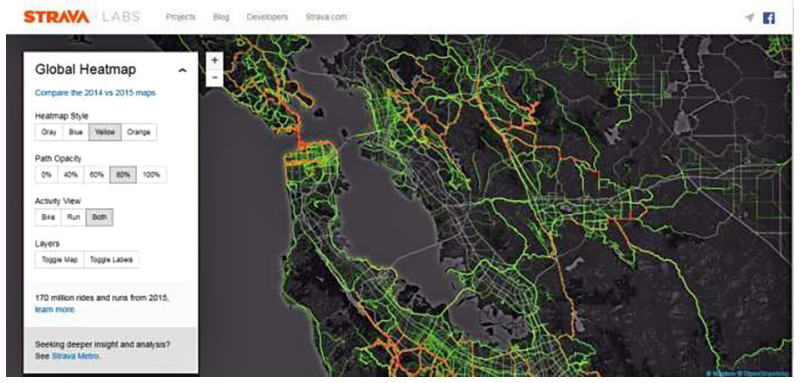

Figure 2. A fragment of a heatmap in Strava service (Strava, 2017)

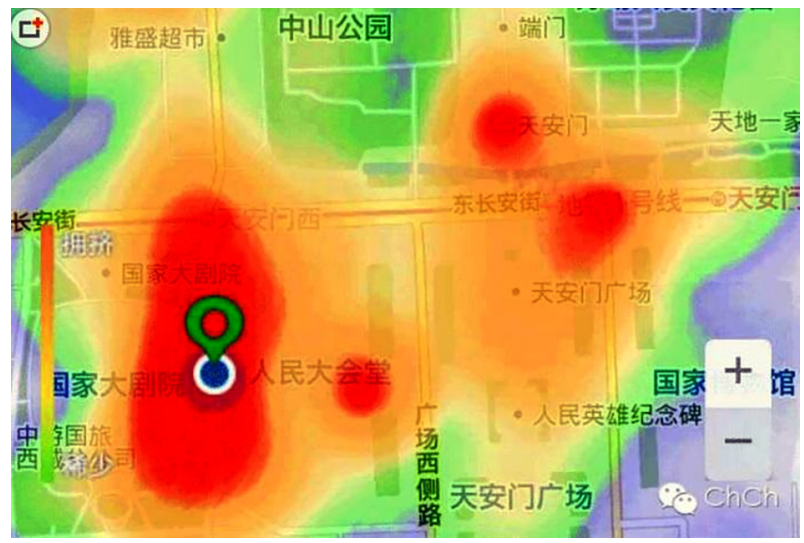

Figure 3. A fragment of a heatmap (pedestrian traffic jams on the roads) (Chuansong, 2017) tourist photographs on Panoramio website that have geolocational information associated with them. Based on the quantity of the photographs, the program shows areas that are the most and the least visited by tourists. In Figure 1, there is a fragment of the heatmap of the central part of Kyiv that shows the areas of tourist attractiveness according to this methodology. Areas in yellow and red colors are the most attractive to tourists.

Sport tourism heatmaps provided by Strava service help to learn about cycling and running activity across the world (Strava, 2017). They are based on tracks recorded by participants of the tracker. For example, In Figure 2, the brightness of the lines on the map shows the popularity of roads for cyclists. The lack of bright colors in densely populated areas could possibly indicate some obstructions (a road closure, wetlands, a steep slope, etc.).

Another example of using heatmaps in tourism is their application for displaying road congestions, in particular, pedestrian traffic jams. Chinese messenger WeChat launched in 2015 a service that shows in real time the density of pedestrian traffic in cities of China. A fragment of a heatmap provided by the service is displayed in Figure 3 . The most congested areas on the heatmap are shown in red.

In order to determine tourist and recreational attractiveness of areas of Ukraine we also create heatmaps. In this work, we rely on QGIS, which is an open-source GIS software. We use as well an open-license OpenStreetMap digital map in the format of ESRI Shapefile that is provided by the GIS-Lab community. The digital map consists of thematic layers and in this work we use the one with the data on Ukraine as of November 2016. The map is available under ODBL license.

Most of tourist objects of the digital map are digitized as point objects (they are located in "poi_point" layer). Some areas of tourist interest (such as parks, gardens, nature reserves, and other) are digitized as polygonal objects (they are stored in "poi_polygon" layer). We include both types of the objects by converting all polygonal objects into point objects (using centroids of the polygonal objects). In the digital map, objects of both layers ("poi_point" and "poi_polygon") are classified according to the following categories: Leisure, Amenity, Tourism, Office, Shop, and Sport. In QGIS we select objects of Tourism category via SQL queries and this way we end up with 10,718 tourist objects in total.

In Figure 4, all the tourist objects are shown as points on the map of Ukraine. The tourist objects that have been digitized include attractions, museums, galleries, religious buildings, and other attractions. The large density of point objects on this map inhibits an analysis of the data and hinders identification of levels of concentration of tourist objects.

A heatmap of tourist and recreational objects created in QGIS is shown in Figure 5. The heatmap is constructed assuming the tourist objects are all of the same weight. A richer database that includes, for example, the number of 


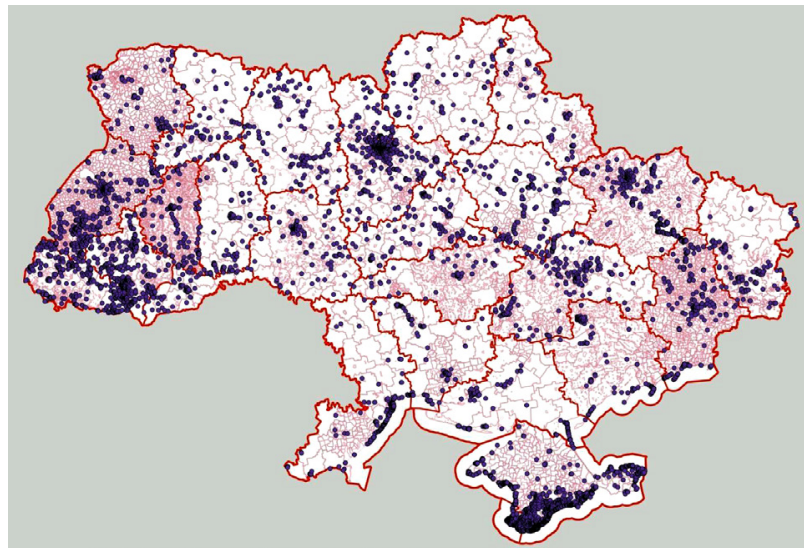

Figure 4. Point mapping of tourist objects on the map of Ukraine

visitors of the tourist places might enhance the heatmap by using object-specific weights. In QGIS, the heatmap is built using plugin "Heatmap". It consists of a raster layer with different colors of each cell of the raster.

QGIS creates heatmaps by assessing the neighborhood (based on the search radius specified by a GIS user) around the center of each cell. The program finds the number of objects in the neighborhood, and it divides that number by the area of the neighborhood. The obtained value is assigned to the cell. This way, the program computes the average number of neighborhood objects across the map, the combination of which is shown as a relatively smooth surface.

The heatmap shows the places of the largest concentration of tourist and recreational objects in Ukraine. They are observed in Kyiv region, in the Carpathian region (Lviv, Truskavets, Drohobych, Yaremche, Bukovel), in Odessa region, in Crimea (Yevpatoriya, Sevastopol and Simferopol, the southern coast of Crimea - from Yalta to Feodosia) and around some regional centers (Vinnytsia, Ternopil, Kharkiv, Zaporizhzhia, Dnipro, Poltava), as well as around some smaller cities: Berdiansk, Sviatohirsk, Mariupol, Shatsk, Bilhorod-Dnistrovskyi (Figure 5).

A heatmap with isolines can be used to refine the results and to display the magnitude of prevalence of tourist objects. A fragment of the map with isolines created in QGIS is shown in Figure 6. A congestion of lines in some places on the map indicates a sharp change of the indicator. By selecting the distance between the isolines (in a dialog of GdalTools plugin used for constructing isolines) it is possible to achieve the desired visual effect. If the distance between the isolines is too small, the lines are difficult to distinguish. If the distance is too large, the details of the distribution are omitted.

Heatmaps allow to show not only the areas with the largest concentration of certain objects, but also to discover the areas in which the objects are missing or found to be in very small quantities. As shown in Figure 7, there are places around which there are no tourist objects. These places remain on the map in white color (as a result of

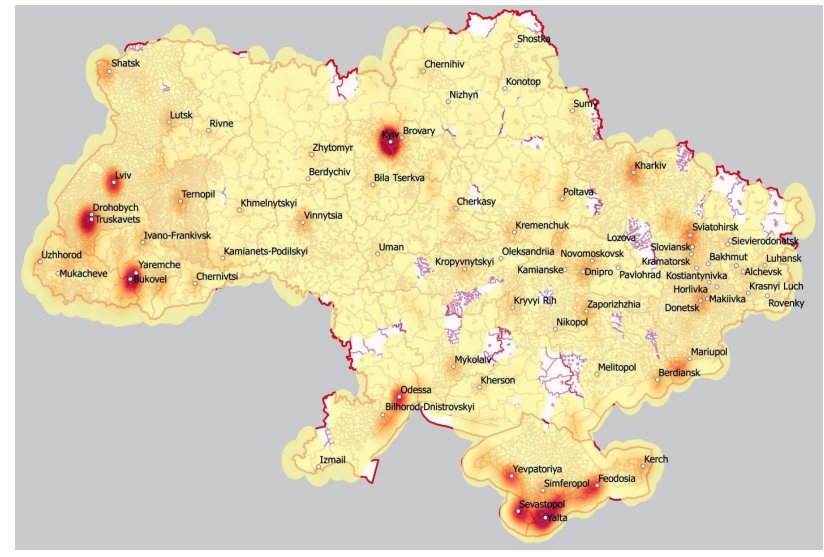

Figure 5. A heatmap (the distribution of tourist and recreational objects on the territory of Ukraine)

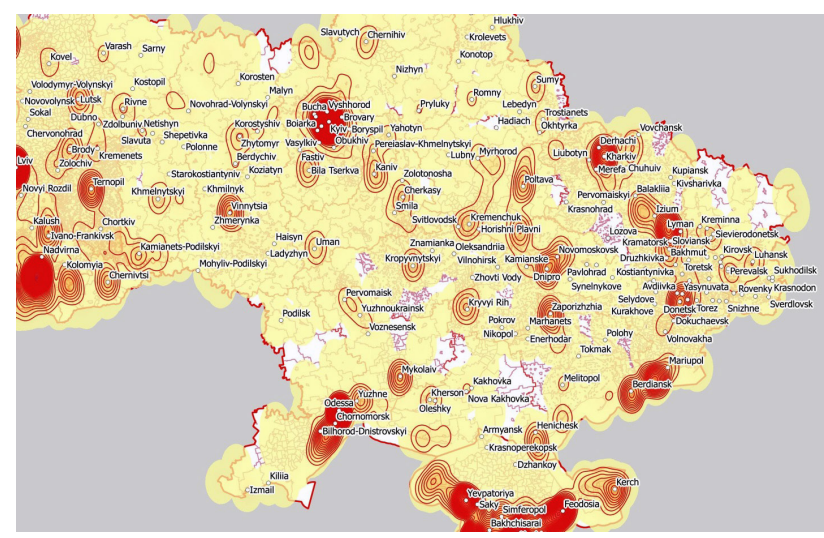

Figure 6. A fragment of a heatmap with isolines (the distribution of tourist and recreational objects on the territory of Ukraine)

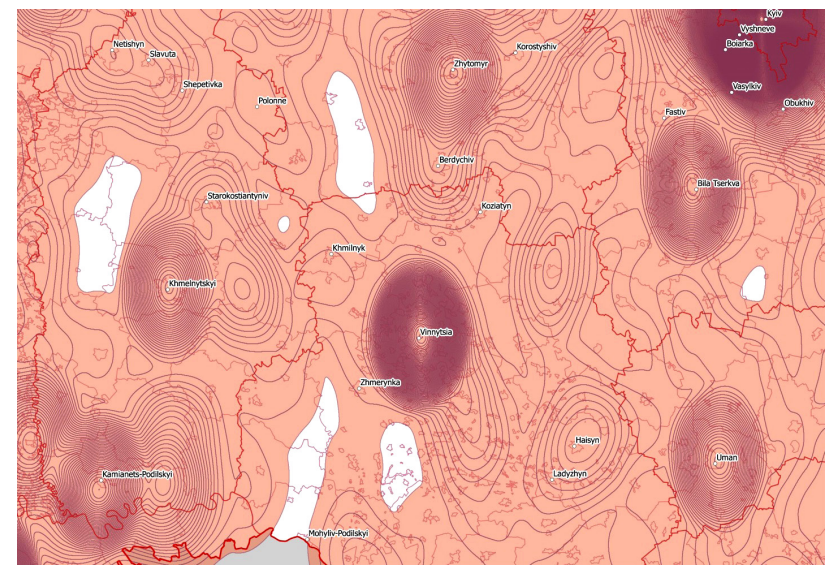

Figure 7. A fragment of a heatmap with white places

interpolation). These areas apparently are not of interest to tourists and less likely to require the development of tourism infrastructure.

Using the database, it is possible to study a particular category of tourist objects and analyze their territorial distribution. For example, heatmaps allow showing the 
distribution of museums (Figure 8), tourist accommodations (Figure 9), and zoos (Figure 10) on the territory of Ukraine.

The museums (897 objects, in total, including palacesmuseums) are located across Ukraine fairly evenly (Figure 8). There are museums in all regional centers and in many populous cities. Most of them are located in or near Kyiv, Lviv, Drohobych, Odessa, Yalta and Sevastopol.

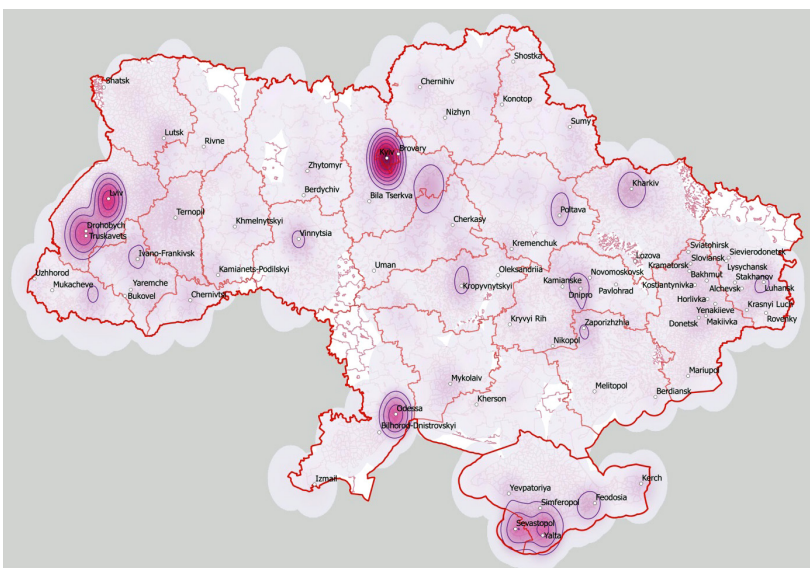

Figure 8. A heatmap (the distribution of museums on the territory of Ukraine)

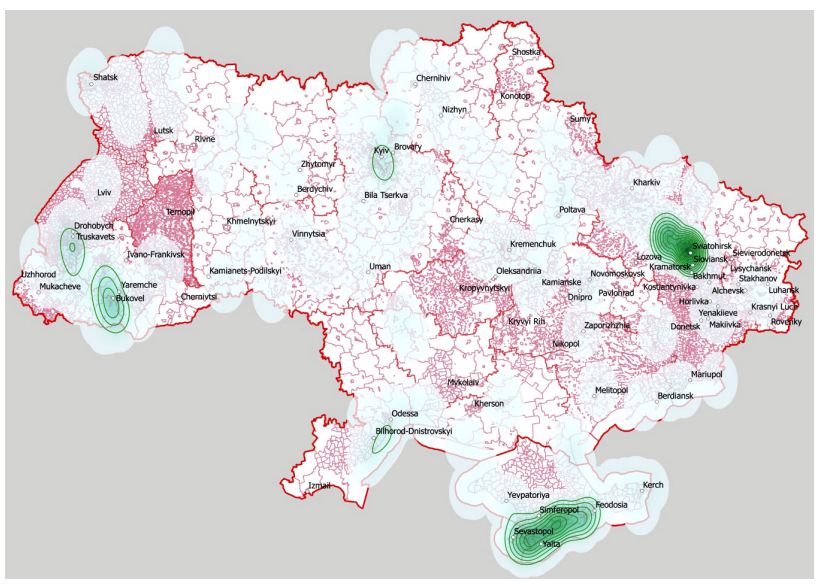

Figure 9. A heatmap (the distribution of tourist accommodation on the territory of Ukraine)

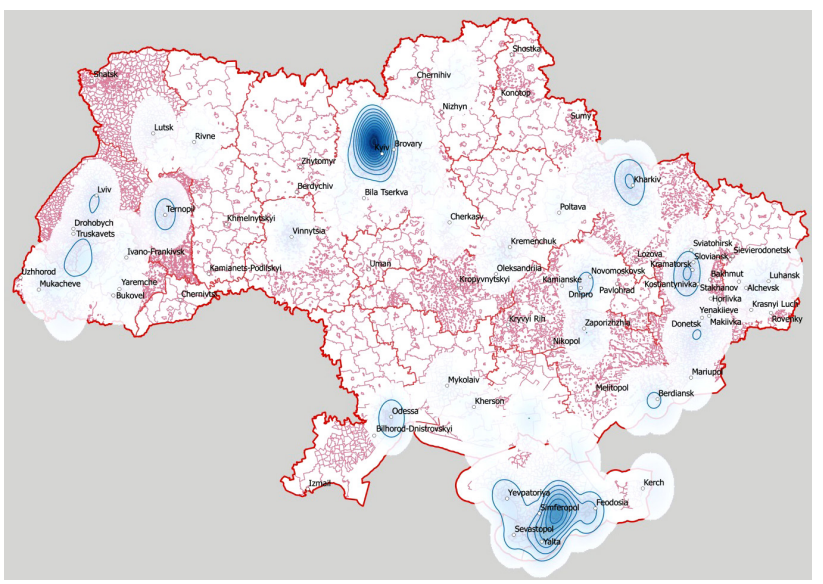

Figure 10. A heatmap (the distribution of zoos in Ukraine)
An analysis of tourist accommodations (820 objects, in total, including resorts, sanatoriums, hostels, campsites, tourist and sport camps, scout camps) show that they are distributed nonuniformly across Ukraine (Figure 9). They are mainly located in the Carpathian region (in Lviv, Transcarpathian and Ivano-Frankivsk regions), and Crimea (the southern coast of Crimea), as well as in Odessa and Kyiv regions. There is also a high concentration of the places between Kharkiv and Donetsk regions.

A distribution of zoos across Ukraine demonstrates substantial irregularity in their locations (Figure 10). This category of tourist objects includes zoos as well as aquariums, dolphinariums, wildlife parks, children's farms, biodomes, etc. (136 objects, in total). The heatmap helps to identify the regions with the largest number of zoos that are Kyiv region and Crimea. A smaller number of zoos are around Kharkiv, Kramatorsk, and in the Carpathian region. There are a few zoos in or around certain cities (Ternopil, Lviv, Odessa, Dnipro, Berdiansk, Yevpatoriya, Sevastopol and Feodosia).

In order to conduct a comprehensive evaluation of tourist attractions it is advisable to create heatmaps based on aggregated indices. We advise to take into account all tourist objects, tourism infrastructure, and climatic and ecological factors. Assigning numerical scores to the factors would make the results more consistent. We also recommend combining the layers of heatmaps by their overlapping. This approach makes the map more informative and allows analyzing the results more deeply.

As an example, in this work we split all tourist objects into two thematic layers. In the first layer, we put all objects of tourist attraction (museums, galleries, zoos, religious buildings, observatories, parks, art centers, monuments, etc.). In the second layer, we include all objects of tourism infrastructure. Among them there are hotels, hostels, motels, summer and guest houses, campsites, trailer parks, places for picnics, rental places of tourist equipment, etc. The objects of tourism infrastructure we show on a heatmap with isolines (blue lines in Figure 11). The objects of tourist attraction we also show on the same heatmap with isolines but using a different color (yellow

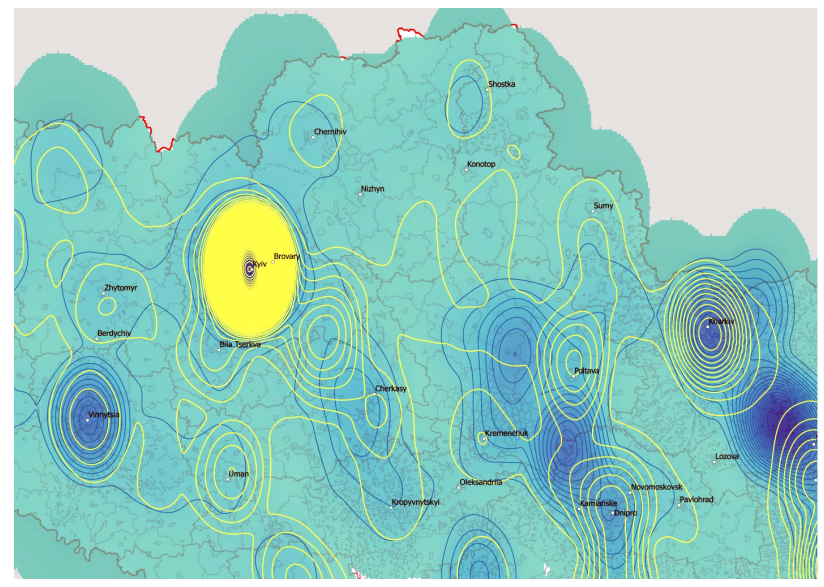

Figure 11. A fragment of a heatmap with overlapping of thematic layers 
lines; they overlap the previous mentioned blue lines). Visually analyzing the map, it could be seen that the tourist attractions and the objects of tourism infrastructure are not always located in the same area. The tourist attractions and tourism infrastructure almost completely coincide, for example, around Shostka or Uman. However, in Sumy region, for example, there are not many objects of tourism infrastructure while there are many attractions. A similar situation is in Chernihiv region. The tourism infrastructure is present there mostly around Chernihiv and near the border with Sumy region and Kyiv region, while in the southern part of the region the tourism infrastructure is practically absent. Based on Figure 11 the development of tourism infrastructure appears to be in line with the prevalence of tourist attractions in the regional centers, particularly in Kyiv, Vinnytsia, Kharkiv, Dnipro, Cherkasy, Zhytomyr (around these cities blue and yellow lines on the heatmap are almost identical).

\section{Conclusions}

Equipped with a database of tourist objects and with an open-source GIS software such as QGIS, it is possible to visualize the most attractive tourist regions of Ukraine. A visual analysis allows detecting some regularities and abnormalities in their location. Tourist heatmaps studied in this work are perhaps the most suitable to demonstrate the degree of irregularity in the distribution of tourist objects. The heatmaps can also be used in the decision-making process on the development of tourism infrastructure.

The results in this work greatly depend on the quality of used database, its completeness, actuality, and reliability. Database updates, the entry of additional tourist objects, and the usage of object-specific weights might improve the obtained results.

In general, the reliance on GIS technology in cartographic methods, and, in particular, the creation of heatmaps for analysis and evaluation of tourist attractiveness are appropriate and promising. They contribute to the development of tourism industry.

\section{References}

Babicki, S. et al. (2016). Heatmapper: web-enabled heat mapping for all. https://doi.org/10.1093/nar/gkw419

Bozhok, A. P., Molochko, A. M., \& Ostroukh, V. I. (2014). Kartoznavstvo: pidruchnik (332 p.). Kiïv: Kiïvs'kiy universitet.

Chuansong. (2017). Retrieved from http://chuansong.me

Danil'chuk, V. F. (2008). Metodika vyyavleniya prioritetnogo osvoeniya turistsko-rekreatsionnykh territoriy na os- nove GIS-tekhnologiy. In V. F. Danil'chuk, N. S. Kudokotsev, \& I. L. Semichastnyy, Visnik DITB. Seriya: Ekonomika, organizatsiya ta upravlinnya pidpriemstvami turistichnoï industriï ta turistichnoï galuzi v tsilomu 12, 25-29.

eSpatial. (2017). Retrieved from https://www.espatial.com

Eck, J. E. (2005). Mapping crime: understanding hot spots. In J. E. Eck, S. Chainey, J. G. Cameron, M. Leitner, \& R. E. Wilson. Retrieved from https://www.ncjrs.gov/pdffiles1/ nij/209393.pdf

Glebova, A. O. (2012). Innovatsiyni tekhnologii u turistichniy galuzi. Ekonomika. Upravlinnya. Innovatsii, 2(8).

Gis lounge. (2017). Retrieved from https://www.gislounge.com/ heat-maps-in-gis/

Heatmaptool. (2017). Retrieved from https://www.heatmaptool. com

Heatmapper. (2017). Retrieved from http://www.heatmapper.ca

Kal'na-Dubinyuk, T. P. (2011). Zastosuvannya suchasnikh informatsiynikh tekhnologiy u rozvitku sil's'kogo zelenogo turizmu v Ukraïni. In T. P. Kal'na-Dubinyuk \& N. A. Pugach, Naukoviy visnik Natsional'nogo universitetu bioresursiv i prirodokoristuvannya Ukraïni (163 ed.), Part 1.

Kolotova, E. V. (1999). Rekreatsionnoe resursovedenie: Ucheb. Posobie (133 p.) Moskva: Rossiyskaya Mezhdunarodnaya akademiya turizma.

Khudo, V. V. (2000). Informatsiyni tekhnologiï v upravlinni turizmom. Problemi informatizatsii rekreatsiynoï ta turistichnö̈ diyal'nosti v Ukraïni: perspektivi kul'turnogo ta ekonomichnogo rozvitku (pp. 161-166). Truskavets'.

Lutay, A. P. (2012). Informatsiyni tekhnologii u turistichniy galuzi: zbirnik materialiv naukovo-praktichnoyi konferentsiyi DonNUET (pp. 241-247). Donets'k.

Mel'nik, A. V. (2009). Vprovadzhennya ta vdoskonalennya geoinformatsiynikh tekhnologiy u turistichniy diyal'nosti. Naukoviy visnik UzhNU (pp. 43-44) (28 ed.). Seriya «Ekonomika».

Mel'nichenko, S. V. (2008). Informatsiyni tekhnologiï v upravlinni sub'ektami turistichnoï diyal'nosti. Visnik KNTEU. Kiïv.

Mitchell, E. (2000). Rukovodstvo po GIS-analizu. Ch. 1: Prostranstvennye modeli $i$ vzaimosvyazi (198 p.). Kiev: ZAO ECOMM Co.

Openheatmap. (2017). Retrieved from http://www.openheatmap. com

Salishchev, K. A. (1990). Kartovedenie (400 p.). Moskva: Izd-vo MGU.

Shakhovs'ka, N. B. (2008). Analiz informatsiynikh sistem obroblennya danikh turistichnoï sferi. In N. B. Shakhovs'ka \& D. I. Ugrin, Naukoviy visnik NLTU Ukraïni (pp. 258-263) (18.10. ed.).

Sightsmap. (2017). Retrieved from http://www.sightsmap.com Strava. (2017). Retrieved from https://labs.strava.com/heatmap 